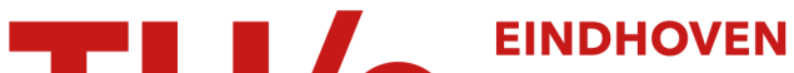 \\ UNIVERSITY OF \\ TECHNOLOGY
}

\section{The optimally performing Fischer-Tropsch catalyst}

Citation for published version (APA):

Filot, I. A. W., Santen, van, R. A., \& Hensen, E. J. M. (2014). The optimally performing Fischer-Tropsch catalyst. Angewandte Chemie, 126(47), 12960-12964. https://doi.org/10.1002/ange.201406521

DOI:

10.1002/ange.201406521

Document status and date:

Published: 01/01/2014

\section{Document Version:}

Publisher's PDF, also known as Version of Record (includes final page, issue and volume numbers)

\section{Please check the document version of this publication:}

- A submitted manuscript is the version of the article upon submission and before peer-review. There can be important differences between the submitted version and the official published version of record. People interested in the research are advised to contact the author for the final version of the publication, or visit the $\mathrm{DOI}$ to the publisher's website.

- The final author version and the galley proof are versions of the publication after peer review.

- The final published version features the final layout of the paper including the volume, issue and page numbers.

Link to publication

\section{General rights}

Copyright and moral rights for the publications made accessible in the public portal are retained by the authors and/or other copyright owners and it is a condition of accessing publications that users recognise and abide by the legal requirements associated with these rights.

- Users may download and print one copy of any publication from the public portal for the purpose of private study or research.

- You may not further distribute the material or use it for any profit-making activity or commercial gain

- You may freely distribute the URL identifying the publication in the public portal.

If the publication is distributed under the terms of Article 25fa of the Dutch Copyright Act, indicated by the "Taverne" license above, please follow below link for the End User Agreement:

www.tue.nl/taverne

Take down policy

If you believe that this document breaches copyright please contact us at:

openaccess@tue.nl

providing details and we will investigate your claim. 


\title{
The Optimally Performing Fischer-Tropsch Catalyst
}

\author{
Ivo A. W. Filot, Rutger A. van Santen, and Emiel J. M. Hensen*
}

\begin{abstract}
Microkinetics simulations are presented based on DFT-determined elementary reaction steps of the FischerTropsch (FT) reaction. The formation of long-chain hydrocarbons occurs on stepped Ru surfaces with $\mathrm{CH}$ as the inserting monomer, whereas planar Ru only produces methane because of slow $C O$ activation. By varying the metal-carbon and metal-oxygen interaction energy, three reactivity regimes are identified with rates being controlled by $\mathrm{CO}$ dissociation, chain-growth termination, or water removal. Predicted surface coverages are dominated by $\mathrm{CO}, \mathrm{C}$, or $\mathrm{O}$, respectively. Optimum FT performance occurs at the interphase of the regimes of limited $\mathrm{CO}$ dissociation and chain-growth termination. Current FT catalysts are suboptimal, as they are limited by $\mathrm{CO}$ activation and/or $\mathrm{O}$ removal.
\end{abstract}

$T_{\text {he Fischer-Tropsch (FT) process converts synthesis gas into }}$ longer hydrocarbons and has become the subject of an intensive research effort driven by the increasing value of liquid energy carriers compared to the ample supply of natural gas. ${ }^{[1]}$ The heterogeneous Fischer-Tropsch reaction is mechanistically complex. Unravelling the relation between the chemical reactions at the surface and the composition of the adsorbed layer poses a great challenge. The mechanism essentially combines a polymerization-type surface reaction, which produces mainly linear hydrocarbons, with the in situ generation of monomers containing a single $\mathrm{C}$ atom. Many uncertainties exist on the nature of the reaction intermediates and hence also on the relative rates of the elementary reaction steps.

Advances in computational catalysis enable detailed studies of surface reactions at the molecular level, thus generating important new and comprehensive information about the relation between the relative stability of surface intermediates and their rate of formation and conversion as a function of catalyst composition and structure.

With respect to the important question of selectivity of the FT reaction, according to one school of thought, small particles are not reactive, as strongly adsorbed $\mathrm{CO}$ inhibits chain growth $;^{[2,3]}$ according to others, step-edge sites are required that are not stable on small particles. ${ }^{[4-6]}$ This explains the observation that selectivity toward the produc-

[*] I. A. W. Filot, Prof. Dr. R. A. van Santen, Prof. Dr. E. J. M. Hensen Schuit Institute of Catalysis, Department of Chemical Engineering and Chemistry, Eindhoven University of Technology PO Box 513, 5600 MB, Eindhoven (The Netherlands) and

Institute for Complex Molecular Systems

Eindhoven University of Technology

PO Box 513, $5600 \mathrm{MB}$, Eindhoven (The Netherlands)

E-mail: e.j.m.hensen@tue.nl

9 Supporting information for this article is available on the WWW under http://dx.doi.org/10.1002/anie.201406521. tion of methane strongly increases and the rate of $\mathrm{CO}$ consumption decreases for smaller transition-metal nanoparticles. $^{[5,7]}$ Microkinetics simulations based on computed molecular reactivity data provide a unique opportunity to resolve such debates. Rate-controlling steps can be deduced, ${ }^{[8]}$ and hence one can identify the nature of particular relevant surface intermediates at specific reaction conditions.

The microkinetics simulation presented herein makes use of DFT quantum-chemical data of the elementary reaction rates of the many reaction intermediates proposed in FT catalysis. ${ }^{[1,9-13]}$ Few of such complete studies exist that not only consider the formation of methane ${ }^{[14]}$ but also include the formation of longer hydrocarbon chains. Earlier microkinetics studies are available that used approximate molecular reactivity data. ${ }^{[6,15-17]}$ Data for the $\mathrm{Ru}(11 \overline{2} 1)$ surface will be compared with predictions for the $\mathrm{Ru}(0001)$ surface. A summary of these data and details of the microkinetic implementation are given in the Supporting Information. The DFT results have been discussed in another paper. ${ }^{[18]}$

The stepped $\mathrm{Ru}(11 \overline{2} 1)$ surface was chosen because its reactive centers have a low barrier for $\mathrm{CO}$ activation and bind reaction intermediates strongly. ${ }^{[19,20]}$ Because the metalcarbon interaction energy is relatively strong, we expected it to show a low rate of formation of methane compared to the production of longer hydrocarbons. ${ }^{[21]}$ We compared it with the dense $\mathrm{Ru}(0001)$ surface, because this surface has a high barrier for $\mathrm{CO}$ activation and can therefore be expected to have a high selectivity for the production of methane. Amongst others, these expectations are based on our previous work with approximate and sometimes estimated values of reaction intermediate data. ${ }^{[6,15,16]}$

The microkinetics simulation data on the $\mathrm{Ru}(11 \overline{2} 1)$ surface showed that under the conditions of the optimum $\mathrm{C}_{20+}$ yield, the reaction rate is controlled by the rate of water formation. This causes the CO consumption rate to be slow with the surface predominantly covered by $\mathrm{O}$ atoms. We have extended these results to reactivity regimes of other catalyst materials by varying the computed reactivity parameters of reaction intermediates using scaling rules, ${ }^{[22]}$ relating the stability of surface species with adsorption energies of atomic $\mathrm{C}$ and $\mathrm{O}$ as reactivity performance parameters. By using Brønsted-Evans-Polanyi (BEP) relations ${ }^{[23,24]}$ in addition to the aforementioned scaling relations, we have constructed a two-dimensional volcano plot ${ }^{[12,25]}$ of CO consumption rate, selectivity, and other relevant kinetic parameters. Three different reactivity regimes can be identified, that is, previously proposed ${ }^{[15,16]}$ regimes limited by monomer formation and chain-growth termination as well as a regime where oxygen removal is limiting. The maximum of the $\mathrm{CO}$ consumption rate is located in between these regimes.

Our model, which takes into account both the carbide and the $\mathrm{CO}$ insertion mechanism, ${ }^{[26]}$ is defined in detail in the 
Supporting Information. All elementary reactions steps, that is, direct and hydrogen-activated $\mathrm{CO}$ dissociation, $\mathrm{CH}_{x}$ hydrogenation, $\mathrm{CH}_{x}-\mathrm{CH}_{y}$ coupling, $\mathrm{CH}_{x}-\mathrm{CO}$ coupling, $\mathrm{CH}_{x} \mathrm{C}-\mathrm{O}$ bond scission, and desorption of hydrocarbon chains as olefins and paraffins are taken into account. To also partially account for the lateral interactions, the $\mathrm{CO}$ adsorption energy is taken as a function of the surface coverage.

Microkinetics results for $\mathrm{Ru}(11 \overline{2} 1)$ show the expected temperature dependence of activity and selectivity (Figure 1). A high probability of chain growth $(\alpha)$ occurs at relatively low temperatures, whereas a high reaction temperature drives the reaction toward $\mathrm{CH}_{4}$. Olefins are the primary reaction products with more than one carbon atom. Predicted $\mathrm{C}_{1}$ and $\mathrm{C}_{2}$ selectivities deviate from the Anderson-Schulz-Flory (ASF) distribution in line with experimental results (Figure $\mathrm{S} 1$ ). The lower $\mathrm{C}_{2}$ selectivity is due to stronger binding and easier chain growth of ethylene compared to higher olefins. ${ }^{[18]}$ The low $\mathrm{CH}_{4}$ selectivity on this surface is consistent with the lower overall barrier for chain growth compared to the overall barrier for the formation of methane. The formation of $\mathrm{CH}_{4}$ is only preferred at high temperature.

To elucidate the salient details of the FT reaction for the $\mathrm{Ru}(11 \overline{2} 1)$ surface, the reaction path from $\mathrm{CO}$ and $\mathrm{H}_{2}$ to hydrocarbons and water was analyzed in detail in a calculated
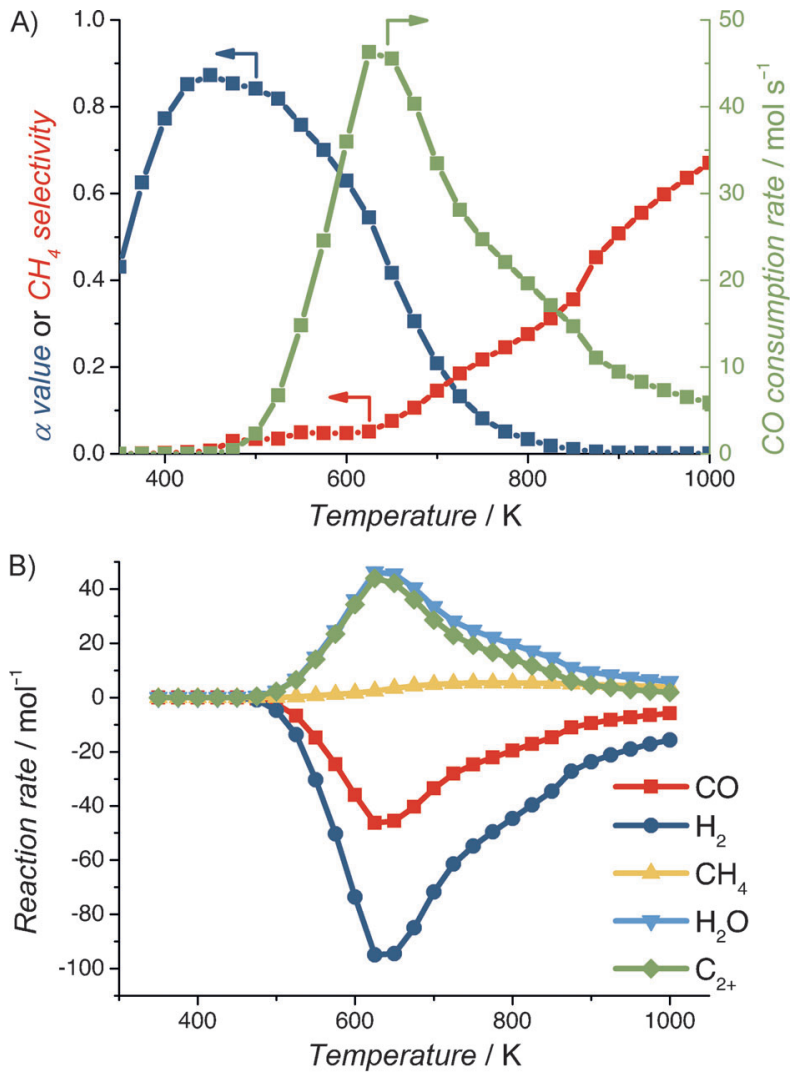

Figure 1. Microkinetics simulations for the $\mathrm{Ru}(11 \overline{2} 1)$ surface $\left(p=20\right.$ atm; $\left.\mathrm{H}_{2} / \mathrm{CO}=2\right)$. A) FT CO consumption rate (green), probability of chain growth (blue), and selectivity for the production of methane (red). B) $\mathrm{CO}$ (red) and $\mathrm{H}_{2}$ (dark blue) consumption rates (negative), and $\mathrm{CH}_{4}$ (yellow), $\mathrm{H}_{2} \mathrm{O}$ (light blue), and $\mathrm{C}_{2+}$ (green) production rates (positive) as a function of the temperature. reaction-intermediate flow scheme at the level of the elementary reaction steps (Figure 2). This analysis was performed at $T=500 \mathrm{~K}$, as we found that at this particular temperature the selectivity toward $\mathrm{C}_{20+}$ hydrocarbons was maximum (see Figure S2). In industry, the formation of longchain hydrocarbons with minimum formation of $\mathrm{CH}_{4}$ is preferred. Figure 2 indicates the relative participation of intermediates in particular reaction steps. As $\mathrm{CO}$ conversion to longer hydrocarbons proceeds exclusively through the insertion of $\mathrm{CH}_{\mathrm{x}}$ intermediates, we omitted $\mathrm{CO}$-insertion pathways. The rate of $\mathrm{CO}$ insertion is very low because of the high barrier of CO insertion as previously discussed. ${ }^{[18]}$ The analysis of the reaction path shows the importance of $\mathrm{CH}$ as the main inserting surface intermediate. The main chaingrowth pathway involves the insertion of $\mathrm{CH}$ into adsorbed $\mathrm{CR}(\mathrm{R}=\mathrm{H}$ or alkyl) growing chains. The resulting surface intermediate $\mathrm{CHCR}$ is then hydrogenated to $\mathrm{CHCHR}$. It turns out to be preferred to first dehydrogenate the $\alpha$-C atom of this fragment before hydrogenating the $\beta-\mathrm{CH}$ group, so that the reaction sequence is $\mathrm{CHCHR}^{*}+* \rightarrow \mathrm{CCHR}^{*}+\mathrm{H}^{*}$ and $\mathrm{CCHR}^{*}+\mathrm{H}^{*} \rightarrow \mathrm{CCH}_{2} \mathrm{R}^{*}+*$. The latter species is represented in Figure 2 by CR. This sequence represents the main chain-growth mechanism. The predominance of chain growth according to the carbide mechanism ${ }^{[26]}$ with $\mathrm{CH}$ is in line with predictions of Cheng et al. ${ }^{[13]}$

The resulting CR species can undergo two hydrogenation reactions of the $\alpha-\mathrm{C}$ atom and one dehydrogenation reaction of the $\beta-\mathrm{CH}_{2} \mathrm{R}$ group to produce the adsorbed olefin $\mathrm{CH}_{2} \mathrm{CHR}^{*}$. This $\mathrm{CH}_{2} \mathrm{CHR}^{*}$ intermediate can either desorb from the surface as the 1-olefin or undergo another dehydrogenation of the $\alpha-\mathrm{C}$ atom to form $\mathrm{CHCHR}^{*}$, which is an intermediate in the chain-propagation route. The high probability of chain growth at intermediate temperature stems from the higher rate of dehydrogenation compared to desorption. Oxygen removal through the formation of water predominantly proceeds through proton migration between two hydroxy groups.

To underpin the importance of the stepped surface for facile CO dissociation, we carried out additional calculations for the less reactive dense $\mathrm{Ru}(0001)$ surface. We used reported data for the dissociation of $\mathrm{CO}$ on this surface. ${ }^{[27,28]}$ Because of the high direct $\mathrm{CO}$ dissociation barrier $\left(>200 \mathrm{~kJ} \mathrm{~mol}^{-1}\right)^{[20,28]}$ the route via formyl (overall barrier $\left.146 \mathrm{~kJ} \mathrm{~mol}^{-1}\right)^{[28]}$ dominates. To model the FT reaction for $\mathrm{Ru}(0001)$, for all other elementary reactions we employed kinetic data determined for the $\mathrm{Ru}(11 \overline{2} 1)$ surface. Under conditions that predict good FT performance for $\mathrm{Ru}(11 \overline{2} 1)$, the planar $\mathrm{Ru}(0001)$ surface only produces methane. Besides difficult $\mathrm{CO}$ dissociation, this is also due to a more facile formation of methane from adsorbed $\mathrm{C}$ on $\mathrm{Ru}(0001)$ $\left(21 \mathrm{~kJ} \mathrm{~mol}^{-1}\right)$ compared with $\mathrm{Ru}(11 \overline{2} 1)\left(86 \mathrm{~kJ} \mathrm{~mol}^{-1}\right)$. The $\mathrm{CO}$ consumption rate is much lower than for the stepped surface.

The conditions for optimal catalytic performance were then analyzed by evaluating the consequences of variations in the activation energies of the elementary reaction steps. These can be related to the interaction energies of the transition-metal surface with $\mathrm{C}$ and $\mathrm{O}$ adatoms using $\mathrm{BEP}$ and scaling law principles. The approach to compute the activa- 


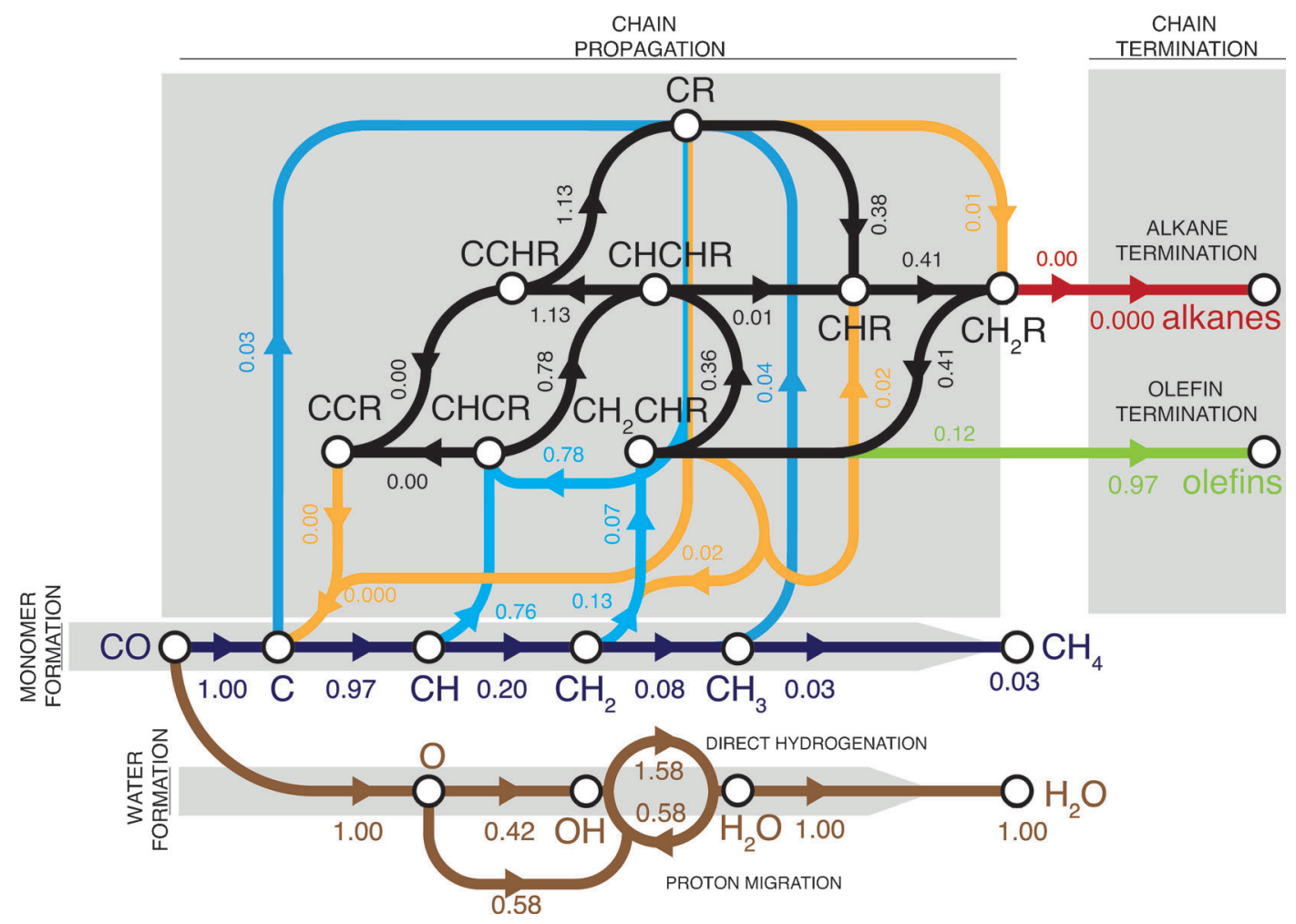

Figure 2. Reaction path analysis for the FT reaction on $\mathrm{Ru}(11 \overline{2} 1)\left(T=500 \mathrm{~K} ; p=20 \mathrm{bar} ; \mathrm{H}_{2} / \mathrm{CO}=2\right)$. The nodes represent reactants, surface intermediates, and products, the lines between them the elementary reaction steps and the numbers molar rates.

tion energies of the various elementary reaction steps relevant to our microkinetic model is outlined in the Supporting Information. Relevant to the discussion below, we exemplify this by the dependence of the activation barrier for $\mathrm{CO}$ dissociation on the strength of the metal $-\mathrm{C}\left(\Delta E_{\mathrm{C}}\right)$ and metal- $\mathrm{O}\left(\Delta E_{\mathrm{O}}\right)$ bond through

$\Delta\left(\Delta E_{\alpha}^{\mathrm{CO}}\right)=\alpha\left(\Delta E_{\mathrm{C}}+\Delta E_{\mathrm{O}}\right)$.

Figure 3 shows the rate of CO consumption as a function of these interaction energies. Microkinetics simulations were performed at $T=500 \mathrm{~K}, p=20 \mathrm{~atm}$, and $\mathrm{H}_{2} / \mathrm{CO}=2$, because it represents the important case in which wax production is maximized. The $\mathrm{CO}$ consumption rate strongly depends on the adatom bond strengths and exhibits a Volcano-type behavior. The predicted rate for the $\mathrm{Ru}(11 \overline{2} 1)$ surface is close to the optimum.

Three distinct regimes can be distinguished in Figure 3 on the basis of differences in the rate-controlling step for the overall FT reaction. These regimes will be discussed below. To facilitate the discussion, Figure 3 also contains contour plots for the most important kinetic parameters for the FT reaction as a function of $\Delta E_{\mathrm{C}}$ and $\Delta E_{\mathrm{O}}$.

In regime $\mathrm{I}$, the $\mathrm{CO}$ consumption rate is controlled by the rate of $\mathrm{CO}$ dissociation. The reaction order with respect to $\mathrm{CO}$ is positive in this regime. The $\mathrm{H}_{2}$ reaction order is slightly negative, because increasing $\mathrm{H}$ coverage lowers the $\mathrm{CO}$ dissociation rate. The apparent activation energy is close to the activation energy for CO dissociation. Decreasing the reactivity of the metal surface (going to the top right-hand corner of the contour plots) will result in a lower probability of chain growth $(\alpha)$. A metal with low reactivity, such as $\mathrm{Ni}$, combines a low rate of $\mathrm{CO}$ dissociation with facile $\mathrm{CH}_{4}$ formation. ${ }^{[29]}$ With increasing metal reactivity, the probability of chain growth strongly increases. In regime I, the FT reaction proceeds in the monomer-formation limit, as earlier discussed by us in a lumped kinetics analysis. ${ }^{[16]}$

In regime II, the rate is limited by the rates of chain growth and chain-growth termination (chain-growth termination limit) ${ }^{[16]}$ Under these conditions, the surface is nearly fully covered with $\mathrm{C}$ and $\mathrm{CH}$ intermediates. Consistent with this, a degree of rate control $\left(\mathrm{X}_{\mathrm{DRC}}\right)$ analysis (Figure S3) shows that the two reaction steps with the greatest $\mathrm{X}_{\mathrm{DRC}}$ are hydrogenation of $\mathrm{CHCR}\left(\mathrm{X}_{\mathrm{DRC}}=0.7\right)$ and desorption of olefins $\left(X_{D R C}=0.3\right)$. The most difficult step is the hydrogenation of CHCR to CHCHR, which is an essential step in the chain-growth mechanism, that is, in the formation of $\mathrm{CCH}_{2} \mathrm{R}$, the intermediate into which the next $\mathrm{CH}$ building block can insert. The slightly positive $\mathrm{CO}$ reaction order in this regime stems from the inhibiting effect of the $\mathrm{C}-\mathrm{CR}$ decoupling step $\left(\mathrm{X}_{\mathrm{DRC}}=-0.5\right)$, which requires free sites. With increasing $\mathrm{CO}$ partial pressure, the fraction of free sites decreases and, accordingly, also the rate of decoupling decreases. This increases the overall $\mathrm{CO}$ consumption rate. The $\mathrm{H}_{2}$ reaction order is strongly positive, because chain growth requires several hydrogenation steps. Typically, the apparent activation energies in this regime are small or can even take negative values. The apparent activation energy is negative, when with increasing temperature vacancies are created as a result of product desorption. The increased vacancy concentration increases the CCR decoupling rate, which lowers the overall $\mathrm{CO}$ consumption rate. Figure 3 
A)
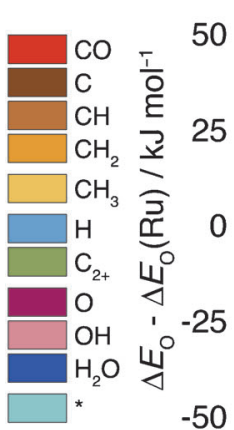

$-50$

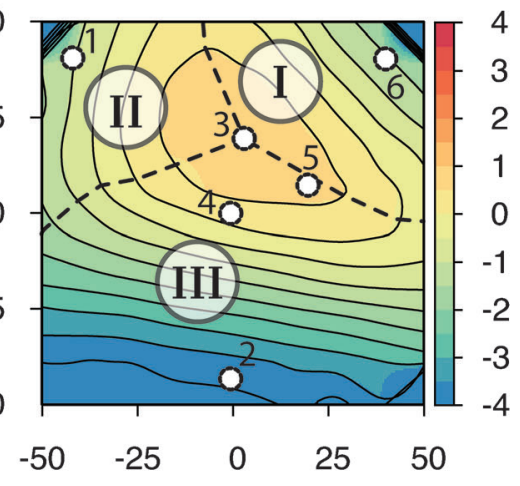

$\log \left(r_{\mathrm{CO}}\right) /-$

$\Delta E_{\mathrm{c}}-\Delta E_{\mathrm{C}}(\mathrm{Ru}) / \mathrm{kJ} \mathrm{mol}^{-1}$

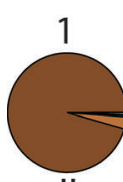

II
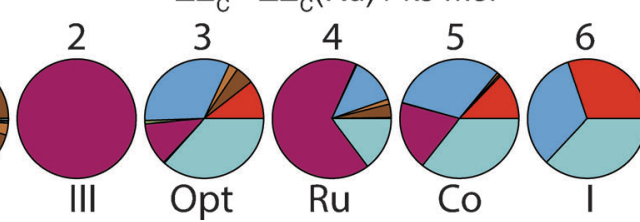

B)
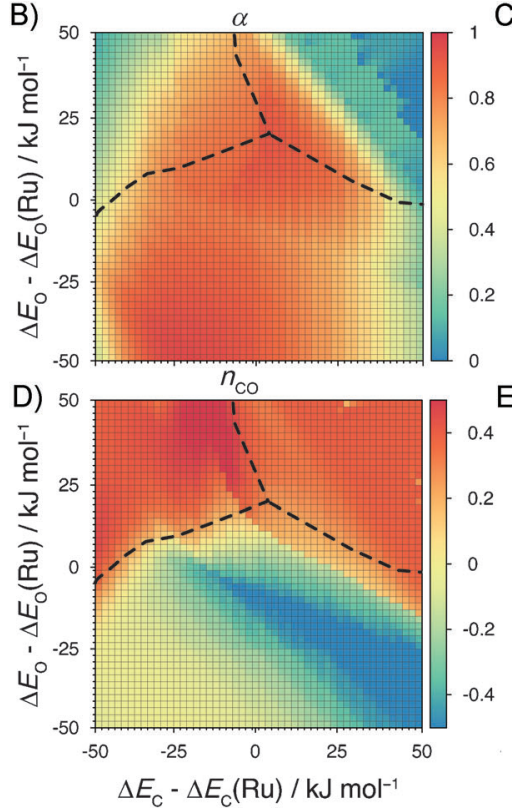

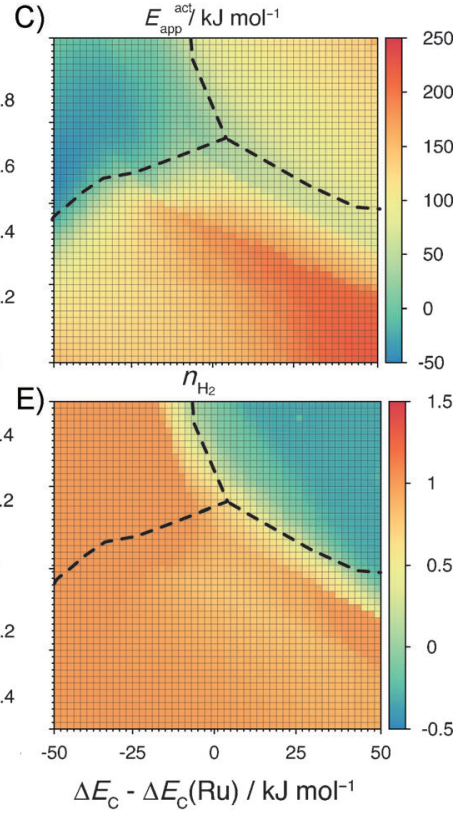

Figure 3. A) CO consumption rate and steady-state surface coverages (the numbers in the graph refer to the numbers above the pie charts) as a function of the metal-carbon and metal-oxygen bond strength $\left(T=500 \mathrm{~K} ; p=20\right.$ bar; $\left.\mathrm{H}_{2} / \mathrm{CO}=2\right)$. The activation barriers for all elementary reaction steps were scaled to the metal-carbon and metal-oxygen bond strengths. Three regimes are distinguished based on the nature of the rate-controlling step, that is, CO dissociation (regime I), chain growth and chain-growth termination (regime II), and water formation (regime III). The positions of Ru and Co metals are indicated on the basis of the strengths of their metal-carbon and metal-oxygen bonds. B-E) Simulated kinetic parameters for the FT reaction $\left(T=500 \mathrm{~K} ; p=20\right.$ bar; $\left.\mathrm{H}_{2} / \mathrm{CO}=2\right)$ as a function of $\Delta E_{\mathrm{C}}$ and $\Delta E_{\mathrm{O}}$ relative to the respective values for $\mathrm{Ru}(11 \overline{2} 1)$. B) Chain-growth probability, C) apparent activation energy $\left.\left(\mathrm{k} / \mathrm{mol}^{-1}\right), \mathrm{D}\right)$ reaction order with respect to $\mathrm{CO}$, and $\left.\mathrm{E}\right)$ reaction order with respect to $\mathrm{H}_{2}$.

shows that the probability of chain growth strongly decreases, if the $\mathrm{M}-\mathrm{C}$ interaction energy becomes very strong, which leads to high activation barriers for the hydrogenation reactions.

While the formation of methane requires only the hydrogenation of carbon, chain growth requires both hydrogenation of the $\mathrm{C}$ atom to $\mathrm{CH}$ for monomer insertion as well as subsequent hydrogenation of the growing hydrocarbon chain. Consequently, the formation of methane will become preferred over chain growth at a high metal- $\mathrm{C}$ interaction energy.

Regime III is representative for surfaces to which oxygen binds strongly. Then, the removal of water can become the rate-controlling step. Candidate rate-controlling elementary reaction steps are $\mathrm{OH}$ hydrogenation to $\mathrm{H}_{2} \mathrm{O}$ and proton migration between two $\mathrm{OH}$ species to form $\mathrm{O}$ and $\mathrm{H}_{2} \mathrm{O}$. This is consistent with $\mathrm{O}$ being the most abundant surface intermediate. High $\Delta E_{\mathrm{O}}$ implies that the barrier for $\mathrm{CO}$ dissociation is low. Consequently, the $\mathrm{CO}$ reaction order is negative. For relatively low $\Delta E_{\mathrm{C}}$ the apparent activation energy is very high because the $\mathrm{O}$ atom needs to be removed from the surface. When the metal-carbon interaction energy increases, the surface-adsorbed layer will contain an increasing amount of $\mathrm{C}$ and $\mathrm{CH}$ intermediates as well as growing chains instead of $\mathrm{O}$. This results in an increase of the $\mathrm{CO}$ consumption rate and the probability of chain growth, and a decrease of the apparent activation energy. For high $\Delta E_{\mathrm{C}}$, the $\mathrm{CO}$ consumption rate and the chain-growth probability decrease again, because $\mathrm{C}$ hydrogenation becomes difficult.

The maximum CO consumption rate at $T=500 \mathrm{~K}$ and $p=$ $20 \mathrm{~atm}$ is obtained for $\Delta E_{\mathrm{C}}=2.1$ and $\Delta E_{\mathrm{O}}=20.2 \mathrm{~kJ} \mathrm{~mol}^{-1}$.
Consistent with the Sabatier principle ${ }^{[23,26]}$ this maximum is the result of the competition of several competing elementary reaction steps. In this case, $\mathrm{OH}$ hydrogenation $\left(\mathrm{X}_{\mathrm{DRC}}=0.47\right)$, CO dissociation $\left(\mathrm{X}_{\mathrm{DRC}}=0.19\right), \mathrm{CH}_{2}+\mathrm{CHR}$ coupling $\left(\mathrm{X}_{\mathrm{DRC}}=\right.$ $0.12), \mathrm{C}+\mathrm{CR}$ coupling $\left(\mathrm{X}_{\mathrm{DRC}}=0.078\right)$, and CHCHR hydrogenation $\left(\mathrm{X}_{\mathrm{DRC}}=0.045\right)$ determine the maximum of the $\mathrm{CO}$ consumption rate. The surface coverages at this optimum are $\theta_{\mathrm{CO}} \approx 0.11, \theta_{\mathrm{O}} \approx 0.12, \theta_{\mathrm{H}} \approx 0.33, \theta_{\mathrm{C}} \approx 0.05, \theta_{\mathrm{CH}} \approx 0.02, \theta_{\mathrm{C} 2+}$ $\approx 0.01$, and $\theta^{*} \approx 0.37$. The $\mathrm{CO}$ and $\mathrm{H}_{2}$ reaction orders are 0.30 and 0.66 , respectively, and the apparent activation energy is $37 \mathrm{~kJ} \mathrm{~mol}^{-1}$. The probability of chain growth is high with 0.92 . The reaction order in $\mathrm{CO}$ is higher than typically found in experiments, whereas the apparent activation energy is lower. ${ }^{[11,30,31]}$ This indicates that FT synthesis using Ru or Co catalysts is not conducted at the optimum performance potential. Although the simulated catalyst optimum depends on the chosen parameters for the $\mathrm{CO}$ adsorption energy, increasing or decreasing the adsorption energy of $\mathrm{CO}$ to simulate different $\mathrm{CO}$ coverages does not alter this finding (see the Supporting Information).

By comparing the simulated reaction orders and activation energies with experimental data, ${ }^{[11,30-32]}$ we deduce that current FT catalysts operate somewhere between regimes I and II. The FT reaction on Ru metal proceeds in the chaingrowth limit with a surface partially poisoned by $\mathrm{O}$ adatoms, whereas on Co surfaces the reaction occurs in the monomerformation limit. In this case, $\mathrm{CO}$ dissociation is controlling the rate, consistent with the general assumption in kinetic studies for the Co-catalyzed FT reaction. ${ }^{[10,11,31]}$ Another important aspect of our findings is that in these regimes, the coordinative 
unsaturated surface metal atoms in the step-edge site are not poisoned by $\mathrm{C}$ adatoms ${ }^{[2]}$ that are formed upon $\mathrm{CO}$ dissociation. Our analysis shows that this is because of rapid $\mathrm{CH}$ intermediate formation, the key chain-growth monomer. The present work also shows that production of long-chain hydrocarbons is consistent with high CO coverage, as even at relatively high $\mathrm{CO}$ coverage a high rate of chain growth can be maintained. Increasing the $\mathrm{CO}$ adsorption energy does not change this result, but leads to a shift of the reaction maximum to higher temperatures (see the Supporting Information). Finally, this study identifies sites with a low barrier for $\mathrm{CO}$ dissociation as the locus of the FT reaction. This implies that the FT reaction with low selectivity for the production of methane will take place on a relatively small part of the surface of the catalytic nanoparticles. ${ }^{[33]}$ Dense surfaces with low reactivity are the locus of $\mathrm{CO}$ hydrogenation to methane.

Received: June 24, 2014

Published online: August 28, 2014

Keywords: Fischer-Tropsch synthesis - kinetics . periodic trends $\cdot$ reaction mechanisms $\cdot$ ruthenium

[1] F. Fischer, H. Tropsch, Brennst.-Chem. 1923, 4, 276; F. Fischer, H. Tropsch, Brennst.-Chem. 1926, 7, 79-116.

[2] K. Fei Tan, J. Xu, J. Chang, A. Borgna, M. Saeys, J. Catal. 2010 274, 121 - 129; D. J. Moodley, J. van de Loosdrecht, A. M. Saib, M. J. Overett, A. K. Datye, J. W. Niemantsverdriet, Appl. Catal. A 2009, 354, 102-110.

[3] M. Saeys, K. F. Tan, J. Chang, A. Borgna, Ind. Eng. Chem. Res. 2010, 49, 11098-11100; D.-K. Lee, J.-H. Lee, S.-K. Ihm, Appl. Catal. 1988, 36, 199-207.

[4] X.-Y. Quek, I. A. W. Filot, R. Pestman, R. A. van Santen, V. Petkov, E. J. M. Hensen, Chem. Commun. 2014, 50, 6005.

[5] R. A. Van Santen, Acc. Chem. Res. 2009, 42, 57-66.

[6] R. A. van Santen, M. M. Ghouri, S. Shetty, E. J. M. Hensen, Catal. Sci. Technol. 2011, 1, 891-911.

[7] J. P. den Breejen, P. B. Radstake, G. L. Bezemer, J. H. Bitter, V. Frøseth, A. Holmen, K. P. d. Jong, J. Am. Chem. Soc. 2009, 131, 7197-7203.

[8] C. Stegelmann, A. Andreasen, C. T. Campbell, J. Am. Chem. Soc. 2009, 131, 8077-8082; C. T. Campbell, J. Catal. 2001, 204, $520-524$.

[9] P. Biloen, J. N. Helle, W. M. H. Sachtler, J. Catal. 1979, 58, $95-$ 107; P. Biloen, W. M. H. Sachtler in Advanced Catal., Vol. 30 (Eds.: H. P. D. D. Eley, B. W. Paul), Academic Press, 1981, pp. 165-216; R. B. Anderson, The Fischer-Tropsch Synthesis, Academic Press, New York, 1984; Z.-P. Liu, P. Hu, J. Am. Chem. Soc. 2002, 124, $11568-11569$; J. Cheng, X.-Q. Gong, P. Hu, C. M. Lok, P. Ellis, S. French, J. Catal. 2008, 254, 285 -295; X.-Q. Gong, R. Raval, P. Hu, J. Chem. Phys. 2005, 122, 024711; J. Cheng, P. $\mathrm{Hu}$, P. Ellis, S. French, G. Kelly, C. M. Lok, Top. Catal. 2010, 53, $326-337$.

[10] A. Outi, I. Rautavuoma, H. S. van der Baan, Appl. Catal. 1981, 1, 247-272; I. C. Yates, C. N. Satterfield, Energy Fuels 1991, 5, $168-173$.

[11] B. W. Wojciechowski, Catal. Rev. 1988, 30, 629-702.

[12] J. Cheng, P. Hu, J. Am. Chem. Soc. 2008, 130, $10868-10869$.

[13] J. Cheng, P. Hu, P. Ellis, S. French, G. Kelly, M. C. Lok, J. Phys. Chem. C 2008, 112, 6082-6086.
[14] M. Ojeda, R. Nabar, A. U. Nilekar, A. Ishikawa, M. Mavrikakis, E. Iglesia, J. Catal. 2010, 272, 287-297; B. T. Loveless, C. Buda, M. Neurock, E. Iglesia, J. Am. Chem. Soc. 2013, 135, 6107-6121.

[15] A. J. Markvoort, R. A. van Santen, P. A. J. Hilbers, E. J. M. Hensen, Angew. Chem. Int. Ed. 2012, 51, 9015-9019; Angew. Chem. 2012, 124, 9149-9153; R. A. Van Santen, A. J. Markvoort, I. A. W. Filot, M. M. Ghouri, E. J. M. Hensen, Phys. Chem. Chem. Phys. 2013, 15, 17038-17063.

[16] R. A. van Santen, A. J. Markvoort, M. M. Ghouri, P. A. J. Hilbers, E. J. M. Hensen, J. Phys. Chem. C 2013, 117, 4488-4504.

[17] S. Storsæter, D. Chen, A. Holmen, Surf. Sci. 2006, 600, $2051-$ 2063; G. Lozano-Blanco, J. Thybaut, W. K. Surla, P. Galtier, G. B. Marin, Oil Gas Sci. Technol. 2006, 61, 489-496; G. LozanoBlanco, J. W. Thybaut, K. Surla, P. Galtier, G. B. Marin, Ind. Eng. Chem. Res. 2008, 47, 5879-5891.

[18] Advance article, "Quantum chemistry of the Fischer-Tropsch reaction catalysed by a stepped Ruthenium surface": I. A. W. Filot, R. A. v. Santen, E. J. M. Hensen, Catal. Sci. Technol. 2014, 4, 3129-2140.

[19] S. G. Shetty, A. P. J. Jansen, R. A. van Santen, J. Phys. Chem. C 2008, 112, 14027-14033; S. Shetty, A. P. J. Jansen, R. A. van Santen, J. Am. Chem. Soc. 2009, 131, 12874-12875.

[20] S. Shetty, R. A. van Santen, Catal. Today 2011, 171, 168-173.

[21] J. Cheng, P. Hu, P. Ellis, S. French, G. Kelly, C. M. Lok, J. Phys. Chem. C 2009, 113, 8858-8863.

[22] F. Abild-Pedersen, J. Greeley, F. Studt, J. Rossmeisl, T. R. Munter, P. G. Moses, E. Skúlason, T. Bligaard, J. K. Nørskov, Phys. Rev. Lett. 2007, 99, 016105.

[23] R. A. v. Santen, M. Neurock, S. G. Shetty, Chem. Rev. 2010, 110, $2005-2048$.

[24] B. Hammer, J. K. Nørskov in Advanced Catal., Vol. 45 (Ed.: H. K. Bruce C. Gates), Academic Press, New York, 2000, pp. 71-129; A. Michaelides, Z. P. Liu, C. J. Zhang, A. Alavi, D. A. King, P. Hu, J. Am. Chem. Soc. 2003, 125, 3704-3705; T. Bligaard, J. K. Nørskov, S. Dahl, J. Matthiesen, C. H. Christensen, J. Sehested, J. Catal. 2004, 224, 206-217; V. Pallassana, M. Neurock, J. Catal. 2000, 191, 301 - 317; J. K. Nørskov, T. Bligaard, A. Logadottir, S. Bahn, L. B. Hansen, M. Bollinger, H. Bengaard, B. Hammer, Z. Sljivancanin, M. Mavrikakis, Y. Xu, S. Dahl, C. J. H. Jacobsen, J. Catal. 2002, 209, 275-278.

[25] A. C. Lausche, A. J. Medford, T. S. Khan, Y. Xu, T. Bligaard, F. Abild-Pedersen, J. K. Nørskov, F. Studt, J. Catal. 2013, 307, 275 282.

[26] R. A. van Santen, I. M. Ciobîcă, E. van Steen, M. M. Ghouri in Advanced Catal., Vol. 54 (Eds.: C. G. Bruce, K. Helmut), Academic Press, New York, 2011, pp. 127-187.

[27] I. M. Ciobica, F. Frechard, R. A. van Santen, A. W. Kleyn, J. Hafner, J. Phys. Chem. B 2000, 104, 3364-3369.

[28] I. M. Ciobica, R. A. van Santen, J. Phys. Chem. B 2003, 107, $3808-3812$.

[29] J. Sehested, S. Dahl, J. Jacobsen, J. R. Rostrup-Nielsen, J. Phys. Chem. B 2004, 109, 2432-2438; M. P. Andersson, F. AbildPedersen, I. N. Remediakis, T. Bligaard, G. Jones, J. Engbæk, O. Lytken, S. Horch, J. H. Nielsen, J. Sehested, J. R. RostrupNielsen, J. K. Nørskov, I. Chorkendorff, J. Catal. 2008, 255, 619; J. E. Mueller, A. C. T. van Duin, W. A. Goddard, J. Phys. Chem. C 2009, 113, 20290-20306.

[30] G. P. Van Der Laan, A. A. C. M. Beenackers, Catal. Rev. 1999, 41, 255 -318; B. Sarup, B. W. Wojciechowski, Can. J. Chem. Eng. 1989, 67, 620-627.

[31] R. Zennaro, M. Tagliabue, C. H. Bartholomew, Catal. Today 2000, 58, 309-319.

[32] M. Claeys, E. van Steen in Stud. Surf. Sci. Catal., Vol. 152 (Eds.: S. André, D. Mark), Elsevier, 2004, pp. 601-680; E. van Steen, H. Schulz, Appl. Catal. A 1999, 186, 309-320.

[33] S. G. Shetty, I. M. Ciobica, E. J. M. Hensen, R. A. van Santen, Chem. Commun. 2011, 47, 9822-9824. 